\title{
PENINGKATAN PEMANFATAN PERAN TEKNOLOGI INFORMASI BAGI PESERTA DIDIK LKP BINTANG MULIA BATUBARA
}

\author{
Romy Aulia*, Mardalius, Febri Dristyan ${ }^{3}$ \\ Program Studi Sistem Informasi, STMIK Royal Kisaran \\ Email: romysinggalang@gmail.com ${ }^{*}$, mardalius18@gmail.com²
}

\begin{abstract}
Community Service Activities in the form of internet utilization training at LKP Bintang Mulia Batubara aim to increase students' knowledge of internet technology and the benefits of the internet and encourage students to be able to independently manage networks and the internet. The target audience in this community service is LKP Bintang Mulia Batubara students. The training method used is a form of training in the classroom using the lecture method, discussion and question and answer. The lecture method used is intended to provide a theoretical explanation of internet and network material. The discussion method is used to explore students' understanding of the material given in lectures. The practice method is used to show directly how to make a network cable. The benefits obtained from this training activity are that students are able to make wired network connections and know the benefits of the internet.
\end{abstract}

Keywords: Internet, Benefits, Training, Networks

Abstrak : Kegiatan Pengabdian Pada Masyarakat berupa pelatihan pemanfaatan internet di LKP Bintang Mulia Batubara bertujuan untuk meningkatkan pengetahuan peserta didik terhadap teknologi internet dan manfaat dari internet serta mendorong peserta didik agar mampu dengan mandiri mengelola jaringan dan internet. Khalayak sasaran dalam pengabdian masyrakat ini adalah peserta didik LKP Bintang Mulia Batubara. Metode pelatihan yang digunakan adalah bentuk pelatihan di dalam kelas dengan menggunakan metode ceramah, diskusi dan tanya jawab. Metode ceramah yang digunakan dimaksudkan untuk memberikan penjelasan secara teori terhadap materi internet dan jaringan. Metode diskusi digunakan untuk menggali pemahaman peserta didik terhadap materi yang diberikan secara ceramah. Metode praktek digunakan untuk menunjukan langsung cara membuat kabel jaringan. Manfaat yang diperoleh dari kegiatan pelatihan ini adalah peserta didik mampu membuat koneksi jaringan dengan kabel serta mengetahui manfaat dari internet.

Kata kunci : Internet, Manfaat, Pelatihan, Jaringan

\section{PENDAHULUAN}

Seiring dengan kemajuan
pengetahuan dan teknologi
komputerisasi, lebih khusus
perangkat lunak, maka baik
secara

langsung maupun tidak dunia
pendidikan juga menuai dampaknya.
Media dalam bahan ajar
memiliki fungsi sebagai alat bantu
untuk memperjelas pesan yang
disampaikan mentor. Media juga


berfungsi untuk pembelajaran individual dimana kedudukan media sepenuhnya melayani kebutuhan belajar peserta didik (pola bermedia). Menurut Briggs (1977) media pembelajaran adalah sarana fisik untuk menyampaikan isi/materi pembelajaran seperti : buku, film, video dan sebagainya. Proses pembelajaran merupakan proses komunikasi dan berlangsung dalam suatu sistem, maka media pembelajaran menempati posisi yang cukup penting sebagai salah satu komponen sistem pembelajaran. Tanpa media, komunikasi tidak akan terjadi dan proses pembelajaran sebagai proses komunikasi juga tidak akan bisa berlangsung secara optimal.

Internet (kependekan

dari interconnection-networking) adalah seluruh jaringan komputer yang saling terhubung menggunakan standar sistem global Transmission

\section{Control Protocol/Internet}

Protocol Suite (TCP/IP) sebagai protokol pertukaran paket (packet switching communication protocol) untuk melayani miliaran pengguna di seluruh dunia.

LKP Bintang Mulia Batubara merupakan pendidikan yang mengutamakan perkembangan keterampilan peserta didik. Keterampilan yang dimiliki merupakan hasil dari pembelajaran di sekolah. Selama ini cara pembelajaran secara tatap muka masih memiliki beberapa kelemahan. Salah satunya adalah perbedaan dari setiap peserta didik dalam menangkap dan mencerna materi pembelajaran. Ada peserta didik yang mengerti, ada yang kurang mengerti, bahkan ada yang tidak mengerti sama sekali. Oleh karena itu, internet memiliki peranan penting dalam hal ini, yaitu dapat membantu mengatasi permasalahan dan kelemahan yang ada. Internet dapat membantu peserta didik mendapatkan ilmu dari luar sekolah, sehingga proses pembelajaran dapat berjalan dengan baik serta peserta didik dapat menangkap dan mencerna materi yang diajarkan oleh Mentor.

Berdasarkan permasalahan yang dijelaskan di atas, maka pengabdian masyarakat ini dilaksanakan untuk memberikan pelatihan mengenai internet sehat dan jaringan.

\section{METODE}

Metode pelaksaan dalam pengabdian masyarakat ini adalah dengan cara melaksanakan kegiatan pelatihan dalam bentuk presentasi, dengan menjelaskan dasar teori dan praktek langsung yang berlokasi di LKP Bintang Mulia Batubara, Kec.Nibung Angus, Kab.Batubara, Sumatera Utara.

\section{PEMBAHASAN}

Pada pelaksanaan Pengabdian Masyarakat ini diberikan terlebih dahulu brainstorming mengenai jaringan komputer dasar.

Manfaat yang didapat dalam membangun jaringan internet komputer, yaitu:

1. Sharing resources

Sharing resources bertujuan agar seluruh program, peralatan atau peripheral lainnya dapat dimanfaatkan oleh setiap orang 
Available online at https://jurnal.stmikroyal.ac.id/index.php/jurdimas

yang ada pada jaringan komputer tanpa terpengaruh oleh lokasi maupun pengaruh dari pemakai.

2. Media Komunikasi

Jaringan komputer memungkinkan terjadinya komunikasi antar pengguna, baik untuk teleconference maupun untuk mengirim pesan atau informasi yang penting lainnya.

3. Integrasi Data

Jaringan komputer dapat mencegah ketergantungan pada komputer pusat, karena setiap proses data tidak harus dilakukan pada satu komputer saja, melainkan dapat didistri-busikan ke tempat lainnya. Oleh sebab inilah maka dapat terbentuk data yang terintegrasi yang memudahkan pemakai untuk memperoleh dan meng-olah informasi setiap saat.

4. Pengembangan dan Peme-liharaan Pengembangan pera-latan dapat dilakukan dengan mudah dan menghemat biaya, karena setiap pembelian komponen seperti printer, maka tidak perlu membeli printer sejumlah komputer yang ada tetapi cukup satu buah karena printer itu dapat digunakan secara bersama-sama. Jaringan komputer juga memudahkan pemakai dalam merawat harddisk dan peralatan lainnya, misalnya untuk memberikan perlin-dungan terhadap sera-ngan virus maka pemakai cukup memusatkan perhatian pada harddisk yang ada pada komputer pusat.

5. Keamanan Data
Sistem Jaringan Komputer dapat memberikan perlin-dungan terhadap data. Karena pemberian dan pengaturan hak akses kepada para pemakai, serta teknik perlindungan terhadap hard-disk sehingga data menda-patkan perlin-dungan yang efektif.

6. Sumber Daya Lebih Efisien dan Informasi Terkini

Dengan pemakaian sumber daya secara bersama -sama, akan mendapatkan hasil yang maksimal dan kualitas yang tinggi. Selain itu data atau informasi yang diakses selalu terbaru, karena setiap ada perubahan yang terjadi dapat segera langsung diketahui oleh setiap pemakai.

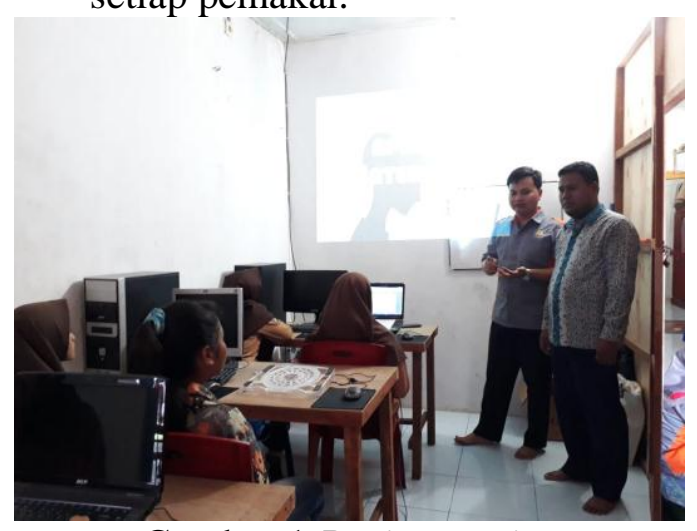

Gambar 1.Brainstorming

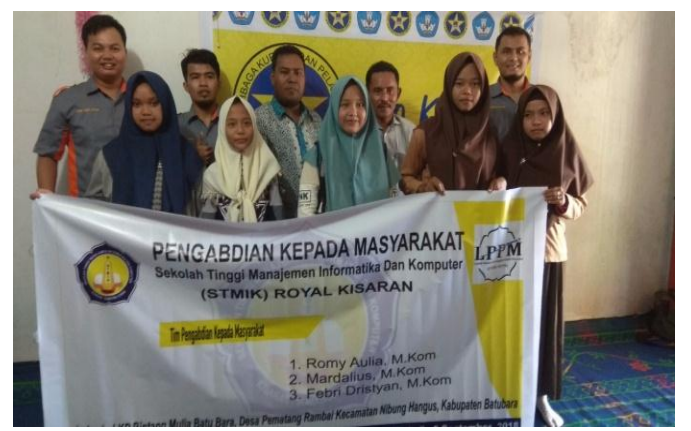

Gambar 2. Tim Abdimas, Pemilik LKP

Bintang Mulia dan sebagian Peserta Didik 
Beberapa aturan (etika) yang ada pada N-Etiket ini adalah:

1. Amankan dulu diri anda, maksudnya adalah amankan semua properti anda, dapat dimulai dari mengamankan komputer anda, dengan memasang anti virus atau personal firewall

2. Jangan terlalu mudah percaya dengan Internet, sehingga anda dengan mudah mengunggah data pribadi anda. dan anda harus betulbetul yakin bahwa alamat URL yang anda tuju telah dijamin keamanannya.

3. dan yang paling utama adalah, hargai pengguna lain di internet, caranya sederhana yaitu,:

a. jangan biasakan menggunakan informasi secara sembarangan, misalnya plagiat.

b. jangan berusaha untuk mengambil keuntungan secara ilegal dari Internet, misalkan melakukan kejahatan pencurian nomor kartu kredit

c. jangan berusaha mengganggu privasi orang lain, dengan mencoba mencuri informasi yang sebenarnya terbatas.

d. jangan menggunakan huruf kapital terlalu banyak, karena menyerupai kegiatan teriakteriak pada komunitas sesungguhnya.

e. jangan flamming (memanasmanasi), trolling (keluar dari topik pembicaraan) ataupun junking (memasang post yang tidak berguna) saat berforum.

Dampak negative internet terutama bagi seorang pelajar:
1. Tidak peduli dan kurangnya sosialisasi terhadap lingkungan, sehingga kemampuan verbalnya kurang.

2. Boros

3. Merusak kesehatan

4. Kurangnya waktu belajar

5. Kurangnya perhatian untuk keluarga, teman dan kerabat.

6. Tersebarnya data pribadi

7. Mudahnya menemui hal yang berbau pornografi.

\section{SIMPULAN}

Dari hasil kegiatan pengabdian masyarakat ini dapat diambil kesimpulan bahwa pengenalan manfaat dan keuntungan internet berhasil dilaksanakan.

\section{DAFTAR PUSTAKA}

Paryanta.(2016). Media Pembelajaran Sistem Jaringan Komputer Dan Internet Berbantuan Komputer Dengan Model Tutorial.Indonesian Journal on Networking and Security (IJNS). $5(2): 1-8$

Yuri., YJ. (2013). Perancangan Program Simulasi Perintah Dasar Jaringan Komputer.Jurnal Ilmiah Foristek. 3 (2) : 294-301

Rini Agustina, S.Kom, M.Pd, (2015), Internet Sehat dan Aman, Jakarta 